Coin Leys, Underdevelopment in Kenya. The Political Economy of Neo-Colonialism. Heinemann, London, 1975, pp. 284, $f 4.00$.

\section{Ronald Dore}

If you want a theory to have a good run for its money, get Colin Leys to embrace it. For when he does he takes it up with complete moral conviction and combines it with a scrupulous honesty about evidence, a power of careful argument and an elegance and incisiveness of style which one normally associates with cool detachment rather than with sectarian conversion.

These qualities make Underdevelopment in Kenya quite the most persuasive example I have yet read of what might be called the transitive view of underdevelopment--the view that the poor countries are not just slow at developing, but have been underdeveloped. It begins with an outline of 'underdevelopment theory', it traces the development of the Kenyan economy since the early colonial period, continues with an analysis of the main elements of the contemporary social structure and then of Kenyan politics, concluding with a few final remarks on where the society is, or rather is not, going.

Those who espouse the 'underdevelopment theory' do not always agree as to the exact contours of underdevelopment, but like other people of different persuasions who use the word 'development' they give it the underlying evaluative sense of 'a change for the better'. Where they differ from traditional 'modernization theorists' is in using 'underdevelopment' to mean not 'lagging in the process of becoming better', but 'having been made worse'.

One thing which is clear from Leys' account is the identity of the people who have made Kenya worse (Leys, to his credit, usually does talk about people-only in occasional rhetorical lapses does he use the 'forces of capitalism' merely to mean 'capitalists' rather than as a legitimate metaphor for tendencies in the economic system. He is not mealy-mouthed in his distribution of moral disapproval, either, though for his more picturesque invective he usually resorts to quotations from Marx.) The dominant group who have been most powerful in shaping modern Kenya are the foreign capitalists who owned and largely continue to own the big plantations, subsequently joined by other foreign corporations who control the expanding banking, commercial and manufacturing sector. (The settler owners of mixed farms were never so very important.) This dominant group has its internal allies, a comprador bourgeoisie made up of African businessmen and large farmers and professional politicians (most of them also businessmen or large farmers) together with the higher bureaucracy (though here Leys is less than usually clear: the bureaucrats are compradors, but they seem not to be properly bourgeois.) The compradors have a certain latitude for independent decision, but it is overwhelmingly constrained by the dominant group. The mechanism of domination is not analysed in detail. There are hints that compradors have direct financial interests in the prosperity of the dominant foreigners -either secretly and corruptly or in the open form of nominal directorships, etc., but the main constraint on their latitude for decision was their need for foreign capital. They depended not just on the non-withdrawal of foreign capital but also (p. 272) on its "continued inflow", therefore no policy must damage the investment climate. Exactly why is not spelled out, but made clear by implication. Expectations of employment and income increases are high among ordinary Kenyans: satisfying those expectations at least in part is a pre-condition for the political survival of the compradors; economic growth is a precondition for increased employment and incomes, and the compradors have no confidence in their ability to achieve it without the capital and associated material and organizational expertise provided by foreigners. Therefore foreign interests must be deferred to. 


\section{The evaluative stance}

Of course this brings one round to asking: why the expectations? Here the analysis is less clear. The mechanisins of underdevelopment are laid bare. but the substance of underdevelopment is not. In what sense has Kenya been "made worse"? "General poverty". we are told on page 230. "was a direct consequence of the whole process of underdevelopment". But. it appears later. that is not quite true. "Although the poor remained poor [in the process of underdevelopment under neo-colonialism] it is doubtful if they became. in aggregate, absolutely poorer. What the mass of the people experienced was. rather. a consolidation of their subjection to the power of capital ". which in practice meant "a continuing prospect of hard. unproductive labour mostly for the benefit of others. accompanied by growing inequality. insecurity. social inferiority and the virtual complete absence of political rights". (p. 258). The major sense in which people are worse off. then. is not in being poorer. but in being made to feel subordinate whereas once they felt equal to any man. insecure whereas once they felt secure. dominated whereas once they felt independent.

One wonders how great these changes have been. As for security. one might doubt whether the climatic and law-and-order circumstances of traditional subsistence farmers ever made people in that part of the world much more secure than they are today. Inequality certainly inhibits brotherhood: there is in that sense an external diseconomy in somebody else getting richer but if the situation is such that $\mathrm{A}^{\circ}$ s getting richer is a pre-condition for B's staying as well-off as he is. $B$ may well prefer that. (And in any case. Leys himself quotes Leakey on the inequality inherent in pre-colonial Kikuyu society.) In the last analysis. it seems. it is the subordination that really gives moral offence.

The predicament of the underdeveloped. says the preface. arises from a structure which "reproduces poverty. inequality. and above all subordination." (p. xiv. my emphasis) The sentiment is a generous one and one would not wish to decry it. but I would have thought that the sense of subordination is more especially felt by the politicians who have to temper their policies to the interests of foreign capitalists, the bureaucrats who have to defer to the superior expertise of expatriate advisers, the managers who are kept in low-ranking personnel positions in foreign firms. the small businessman who cannot get into the protected markets of the foreign firms. the lecturers in political science whose professor is white-in short by the comprador bourgeoisie rather than by the poor. Yet it is in terms of the welfare of the poor. of the exploited and oppressed that. Leys tells us at the beginning of the book. his "better" and "worse" is to be measured (p. xii).

There remains. of course. another sense of 'subordination to which the poor are subject. namely the elementary loss of personal independence which is involved in all transition from subsistence production to wage labour. If one deplores that. then the whole history of European industrialization represents a change for the worse (as. indeed. in some senses the Communist Manifesto implied that it was) and can properly be called underdevelopment. That is a not unreasonable point of view. if one attaches little importance to the material comforts which constitute the mess of pottage for which the European peasantry has been compensated for its birthright. But it is not widely shared. and it does not make the changes in Kenya different in kind from the processes of economic growth that have taken place elsewhere in the course of human history. It merely means that Kenya is less underdeveloped than Britain or the US.

In short. the evaluative standards which Leys uses are not at all clear. There is no doubt that foreign capitalists have gained most from the growth in productivity since colonialism brought European capital and know-how to Kenya; he makes clear. too. that since Independence. continued payment of this tribute has been a precondition for continued access to the capital and know-how. Equally one can accept Leys' judgement that the compradors chose to go on paying that price not because they deemed it 'good for the country' but because they were guaranteed a fairly large slice of the proceeds. But some of the proceeds also go to the labour aristocracy and even. apparently. to the mass of the people. if they are. at the very least. not poorer in spite of population growth. Would they have been better off if the comprador elite had chosen the different strategy which Leys occasionally hints at in his references to the possibilities of nationalization of foreign industry and the creation of state farms?

One can only guess from other examples. If Tanzania is any guide. people would probably have been in aggregate poorer: the elite would certainly have had a stronger sense of national pride in independence. and there might have been a good deal more equality in the distribution of income. But not necessarily: as Guinea shows. nationalism does not necessarily imply greater equality. One of the weaknesses of Leys' analysis is that he does not fully lay bare the necessary interconnections between foreign domination and 
the internal distribution of income. He demonstrates only one part of it; how the interests of foreign capitalists required a free enterprise system of reliance on market forces, tempered by the public and overt use of political power to create protective monopolies, which was bound to lead to inequalities. But he does not show how the other source of inequality, the secret use of administrative power for private enrichment, was necessarily entailed by the neo-colonial struture; hence he gives no reason to suppose that this source of inequality - which can persist in a command economy or be rare in a Singapore-type free enterprise one-would disappear if foreign domination were removed.

One root cause of the fuzziness in Leys' moral evaluations is that he does not face up to the obvious fact that what reproduces poverty in an economic system is the lack of change, and that if poverty is to be cured, investment and innovation have to come from somewhere. From this comes his scornful rejection of the ILO Mission's prescription for fostering indigenous capitalism in the informal sector. The workers in that sector, are, he says, the most exploited. Let us leave aside one sense of exploitation-that the terms of trade between the formal and informal sectors grossly favour the former-for the ILO Mission suggested some things that should be done about that. $\mathrm{He}$ is talking rather of exploitation of workers by their employers. He does not produce evidence of it, however, apart from a vague assertion in the Mission's report that these enterprises are profitable. It is at least possible that the low wages in this sector reflect low productivity rather than high profits. And even if profits were high, surely one would be best advised to think of the possibilities of the workers organizing to get a larger share of them, rather than discouraging the whole business. If capitalist growth is the only kind of growth you can get, is it better to have no growth at all?

I am not sure if Leys' answer to that question is yes, but it seems like it. The fact that he does not really consider the conditions under which poverty can be reduced in the future or could have been reduced if things had been different in the past, confirms the impression that it is indeed "above all" subordination rather than poverty which offends him. In that he is at one with Fanon, whom otherwise he criticises for the imperfections of his class analysis. Such a position, is of course, quite reasonable for a middle-class relatively welloff Fanon. It was a position shared, too, by thousands of poor Algerians at the height of the war of Independence. One wonders though, if it is a position likely to be shared by the mass of the poor people of any country in more humdrum times. One wonders too, whether Colin Leys-who, does after all, claim to be trying to write a book which will serve the interests of the poor people of Kenya-has a right to assume that they do share it.

One final point relating to this whose side are you on' business. Colin Leys says that one has to make up one's mind whose interests one is to serve: those of the compradors or those of the majority who live in poverty. It is a fair point and he is quite right in saying that those who pretend to take no position are in fact taking a position upholding the status-quo. But let us not forget that there are other interests involved besides those of the people written about. We who write in English about developing societies also have our own personal interests - the interest we have in applause from our peers, in being seen to be on the side of the angels. I do not know how widely Kenyans will read Colin Leys' book, but it is a reasonable guess that the book will have more readers in British and North American universities than in Kenya. Qua political, in other words, it is likely to have less significant impact in the jungle of Kenyan politics than in the chattering groves of academe. It also reads like a book which has the latter audience in mind.

\section{Analysis}

So much for attempts to probe the 'deep structure' of value judgements which shape Leys' evaluations of the Kenya situation. There remain one or two doubts about the analysis itself. The central focus is on the 'contradictions' of the system-conflicts of material interest between classes. The analysis here is subtle and draws clear and proper distinctions between the observer's objective perceptions of where the boundaries of common-interest class groups lie and the perceptions-levels of class consciousness - of the people of the society themselves. In the urban sector, he suggests, the class position of the workers is significantly affected by the fact that most of them preserve some stake in rural areas-and in consciousness terms, too, it is still within a rural context that most of them find their primary self-definition. The rural scene it ably described in all its complexity, though in Chapter 3 on agriculture Leys insists on a conflict of interest between small-scale and large-scale producers over pricing policies which-except for certain milk price arrangements which have been abolished-he does not fully explain. Conflict over access to credit, particularly for land purchase, is clearer, though as in all forms of unequal competition between a spectrum of competitors of graduated strengths, this lends itself much less easily to class analysis than capitalist relations of 
employınent. It is ultimately in the growth of capitalist wage labour relations that he sees prospects of an inevitable "process of gradual polarization" in rural areas.

But still, as Leys is careful to point out, that polarization has not gone very far in terms of consciousness.

"In any society that is highly unequal there is a 'margin' where people are poor and have such low social status that they are largely excluded from effective membership in the society. In Kenya in 1970 few people were yet in this position, and in addition the rich and powerful people in the cities were not yet seen as a race apart; their own rural origins were mostly very recent, and while the link between them and the poorest peasants was becoming artificial and mystified, it was still quite active and personal." (p. 190)

But if the very real antagonistic oppositions of class interests do not lead to class consciousness and class organization-or at the most only to embryo organizations which are quickly suppressed-it is a paradox that another kind of consciousness, 'tribalism', is a good deal more overt and productive of effective organization. Kenyans do define themselves in terms of ethnic group membership and very frequently see their ethnic group as being in an antagonistic relationship with other groups.

Leys' explanation of this is clear. In the first place tribalism is a consequence of colonialism, first in the trivial sense that pre-colonial society had little tribalism because there was little contact between tribes, secondly in the more substantial sense that colonial administrators, using tribal organization as an allocative mechanism, deliberately favoured some tribes at the expense of others. But that is less important in his analysis than the continuing deliberate use of tribal rhetoric as "ideology" and "mystification". It serves the interests of those who have power and wealth by directing the antagonism which the poor/ powerless would direct against them if they could perceive their real interests, against, instead, the poor and powerless of other ethnic groups. It mystifies the real antagonistic contradictions between, say, the wealthy and poor Kikuyu by the creation of an artificial, ideological, contradiction between Kikuyu and Luo, or Kikuyu and Kalenjin.

How justified is this contrast between real conflict -over access to land or the level of wages in capitalist agriculture-and the artificial conflicts between tribal groupings which, as Leys records, centre on such things as access to white collar jobs and to the educational opportunities which provide the passport to white collar jobs? (Since educational opportunities are generally provided for local catchment areas and tribes are locally concentrated, competition for educational resources very easily takes on the form of tribal conflict. So, too, does nepotism, since a man's nephews usually belong to his own tribe.)

The best first step to an answer to that question is to calculate the proportion of total personal monetary income derived from public and privatecorporate employment, access to which requires educational certificates. I suspect that it might be larger than the total monetary income derived from agriculture. If so, it is a little perverse to suggest that conflicts which arise over competition for incomes from agriculture are somehow more 'real' than those which arise over the distribution of the other, equally large or larger, share of national income. Apart from a short paragraph discussing the possibility that agricultural wealth could be translated into educational advantage, thus aiding in the hereditary crystallization of class groups, there is little mention of education at all in Leys' analysis. One would never guess from his book that, by all accounts, as many Kenyans seem to centre their aspirations on getting a child to secondary school as on getting an extra few acres of land, or that, reflecting the strength of these aspirations, 30 per cent of government revenue-a good deal more than expenditure on agriculture-is spent on education. All those aspects of modern Kenyan society are no less crucial determinants of who gets what, no less understandable sources of antagonism than the property laws and market forces which determine access to other kinds of resources. For 'real' in Leys' terminology one should really read 'allowed to be important in traditional Marxist analysis'.

And so much the worse, one is inclined to say, for traditional Marxist analysis. Weber most effectively paraphrased Marx's definition of class in terms of relations to the means of production when he spoke of class groups being distinguished by the life-chances inherent in their 'position in the market'-the resources, whether of mere labour power or of capital, which they took into it. That was a perfectly adequate criterion for analysing the main groupings in the political economy of nineteenth century states where markets did in fact play the overwhelmingly dominant allocating role and the state was a mere nightwatchman, holding the ring, sanctioning the property laws and the fulfilment of contracts. But the world has changed. Even in the older industrial economies an increasing proportion of income is allocated through nonmarket bureaucratic means; in the new post- 
colonial nations even more so. The France of Louis Napoleon is not a paradigm for modern Kenya in every respect-certainly not in this one-however rich the Eighteenth Brumaire may be in colourful phrases for describing the dramatis personae.

It is a pity Marxists have to be so very conventional. There are, of course, some writers in the Marxist tradition who recognise the importance of bureaucracy as well as of markets in determining the antagonistic contradictions in societyMao, Djilas, Ossowski, for instance. But to Marxists, I suppose, it is impossible to conceive that these writers might be discussing tendencies visible in all modern societies, socialist and capitalist alike. To a Marxist, socialism and capitalism are chalk and cheese; they each obey their own historical laws, and since Louis Napoleon's France and Kenyatta's Kenya are both capitalist the same analysis should apply. If only the world were so unchangingly straightforward.

There is one other aspect of Marxist analysis as Leys uses it which bothers empiricists like myself and that is its functionalism. Parsonian functionalism assumes that societies are systems which have an inbuilt homeostatic tendency towards stable equilibrium tout court. Marxist functionalism assumes a similar tendency towards equilibrium of a certain sort-one which sustains the hegemony of the dominant capitalist group. Consider the following passage:

"The main economic importance of the 'peasant' modes of production was as a source of foreign exchange for the purchase of manufactured imports and as a source of cheap foodstuffs and of subsidies for wages in the capitalist sector. It was for this reason that they had to be enabled to reproduce themselves. In making economic and social policy the state apparatus had therefore to manage the relationship between the modes of production in such a way that the peasant modes remained 'viable', while offering a minimum of effective competition to the capitalist mode." (pp. 192-3)

Is this a statement about the conscious intentions of those who frame policy towards subsistence agriculture? If so it seems implausible to argue that they really have been moved more by thoughts of the need for a reserve army of labour and cheap wage goods than by the need to get the minimum political support required to keep the regime in power. The most obvious reading of this passage is to see it as postulating some inherent systemic tendency the causal mechanisms of which are obscure but do involve the attribution of purpose to social systems. It is no accident that 'it is no accident that' is a favourite phrase in Marxist analysis. For functionalists of any persuasion no social phenomenon is accidental in the sense of being unrelated to the central purposes of the system. That is what makes such analysis hard to swallow for those of us who cannot accept teleology as among the legitimate explanatory mechanisms of social science.

The distinction between the accidental and the inherent brings me to one final element which seems to be missing from Leys' account of neocolonial domination. He talks several times of the role of foreign capital and know-how. At no point, however, does he address himself to the obvious question: how far is the dominance of foreigners in Kenya due to the fact that theymiddle-class products of several generations of intensive and sophisticated education-can run rings around the first-generation-educated who constitute their Kenyan opposite numbers? Leys gives plenty of evidence in passing of this intellectual domination. Sessional papers, embodying crucial policy principles, are drafted by foreigners; the manifestos of opposition parties bear "clear traces of an expatriate hand" (implication: no Kenyan could write with quite that skill, lucidity, sophistication or whatever); even the professor of that most sensitive university department, Political Science, was until recently the expatriate Colin Leys. This is a genuine and undeniable form of domination-but one which clearly distinguishes Kenya from an India or a Peru or a Singapore, and has little to do with the global forces of world capitalism. As such it has little to do with a generalizable theory of underdevelopment. Whether it is because it would do such damage to the theory, that Leys never squares up to this aspect (and contents himself in the introduction with the general assertion that the theory of underdevelopment explains some countries but not others, without asking why), or whether he avoids the issue simply from a delicate reticence, I have no means of knowing.

In short, Underdevelopment in Kenya is in many ways a brilliant book, lucid in its historical analysis, shrewd in its dissection of the contemporary mechanisms of power and profit, politically useful in its description of who actually is getting what out of the system. Its impact is lessened, first by an ambiguity of sentiment and sympathy one of the results of which is to preclude serious discussion of how things could, or can, be otherwise; secondly by lacunae in the analysis of the whys and wherefores of who gets what: too many of the complexities of the situation are missed because of the insufficiently versatile nature of the Marxist tools of analysis adopted. 